\title{
Satisfaction of European Tourists Regarding Destination Loyalty in Phuket
}

\author{
Aswin Sangpikul ${ }^{1}$, Anan Chieochankitkan ${ }^{2}$, and Suwanchai Hounnaklang ${ }^{3}$ \\ ${ }^{1,2,3}$ Dhurakij Pundit University, Bangkok, Thailand \\ ${ }^{1}$ aswin.sal@dpu.ac.th \\ 2anan.chn@dpu.ac.th \\ ${ }^{3}$ suwan.hou@dpu.ac.th
}

\begin{abstract}
The European travelers market is one of the important international tourist markets to Phuket. However, little is known on their intention to revisit Phuket. Destination loyalty is an important marketing factor in sustaining the destination attractiveness. It is necessary for tourism managers to understand the relationship between tourist destination and destination loyalty to develop proper plans or strategies to attract more repeat tourists to the destination. Thus, this study has an objective to investigate the effect of European tourists' satisfaction on destination loyalty in Phuket. Data were collected from 225 European tourists through the convenience sampling, and were analyzed by the multiple regression analysis. The findings revealed that tourist satisfaction on natural environment, local culture, and safety were found to affect tourists' destination loyalty. Recommendations for Phuket's tourism industry are addressed.
\end{abstract}

Keywords: tourist satisfaction, destination loyalty, European tourist, Phuket

\section{Introduction}

With the rapid growth of tourism industry in Thailand, toady tourism has been regarded as one of the most important tools used to boost economies and promote country's development. The growth of tourism in Southeast Asia has developed very fast and each country is attempting to promote tourism to generate revenues to the country. Every nation has developed various marketing campaigns to persuade tourists to visit its state by promoting attractive destinations, local culture, food, architecture, folklore and man-made attractions. As tourism industry makes lots of benefits to the country, particularly the economic contributions, the Thai government has established various national policies to develop Thailand's tourism continuously. Phuket is Thailand's the largest island and the only province-island in the country. It has many beautiful natural attractions, particularly the beaches and small islands. Phuket is not only well-known for its beach tourism but also the charming sub-cultures (e.g. Thai, Chinese and Muslim) and historical attractions. Phuket has attracted millions of people from all over the world for decades. Since Phuket is rich in the natural resources, particular the image of beach tourism, and becomes the top tourist destinations in Thailand, it, therefore, is chosen as the area of investigation on the destination loyalty due to its high potentiality to attract loyal/repeat tourists. Furthermore, the European tourists are the focus of this study because they are the largest market segment visiting Phuket [2]. Nevertheless, there are limited studies exploring this segment, particularly their travel satisfaction and intention to revisit the same destination. This study therefore has an objective to investigate the effect of European tourists' satisfaction on destination loyalty in Phuket. Understanding this issue may help the local authorities develop appropriate strategies to attract and increase European tourist arrivals to Phuket, particularly the number of repeat visitors and economic revenues. 


\section{Methodology}

The samples in this study were European travelers (aged 20 years older and over) who traveled independently to Phuket. Using a convenience sampling method, data were collected at major tourist attractions in Phuket (city and beaches) through a closed-ended, self-administered questionnaire. During the survey (May 2015), the respondents were asked if they would be interested to participate in the survey. A total usable of 225 questionnaires were obtained during the survey since this research was a part of a larger research project. Several prior studies with $200-300$ usable questionnaires were argued for their sufficiency to provide statistical analysis $[1,4]$. The questionnaire was developed from a review of previous studies focusing tourist satisfaction $[1,4,5]$. According to the literature, tourist satisfaction is generally measured by 2 items: (1) attribute satisfaction and (2) overall satisfaction [1,4,6]. The eighteen destination attributes were reviewed from related literature $[1,4,6]$, and were modified to correspond to Phuket's destination features (i.e. beaches, leisure activities, culture, services, and tourism environment). The respondents were asked to evaluate their satisfaction on 5-point Likert scale ( $5=$ very satisfied and $1=$ very dissatisfied). With regard to destination loyalty, most prior studies have measured destination loyalty on two items: (1) the intention to revisit the destination in the future and (2) the likelihood to recommend the destination to other people [1,5,7]. Following the literature, this study asked the respondents to rate their intention to revisit Phuket in the near future, and their likelihood to recommend Phuket to their relatives/friends by using a 5-point Likert scale ( $1=$ least likely and $5=$ most likely).

A reliability analysis (Cronbach's alpha) was performed for tourist satisfaction (attribute satisfaction) with a result of 0.89 , exceeding the minimum standard $(0.80)$ [3]. The validity test (face validity) was also undertaken to obtain feedback and comments on the clarity and appropriateness of the research questions. Descriptive statistics (percentage, mean, S.D.) were used to describe respondents' profile, mean score of tourist satisfaction and destination loyalty while inferential statistics (multiple regression analysis) were used to analyze the impact of tourist satisfaction (independent variable) on destination loyalty (dependent variable).

\section{Findings}

Table 1: Profile of research respondents

\begin{tabular}{|c|c|c|c|}
\hline Characteristics & Descriptions & Number $(n=225)$ & Percent $(100 \%)$ \\
\hline \multirow{2}{*}{ Gender } & Male & 120 & $53.0 \%$ \\
\hline & Female & 105 & $47.0 \%$ \\
\hline \multirow[t]{4}{*}{ Age } & $20-30$ years & 63 & $28.0 \%$ \\
\hline & $31-45$ years & 75 & $33.0 \%$ \\
\hline & $46-59$ years & 69 & $31.0 \%$ \\
\hline & 60 years or older & 18 & $8.0 \%$ \\
\hline \multirow[t]{3}{*}{ Marital status } & Married & 140 & $62.0 \%$ \\
\hline & Single & 70 & $31.0 \%$ \\
\hline & Divorced/Separated/Widowed & 15 & $7.0 \%$ \\
\hline \multirow[t]{3}{*}{ Education } & Bachelor degree & 132 & $58.0 \%$ \\
\hline & Master degree or higher & 78 & $35.0 \%$ \\
\hline & High school or lower & 15 & $7.0 \%$ \\
\hline \multirow[t]{6}{*}{ Occupation } & Company employee & 53 & $24.0 \%$ \\
\hline & Government officer & 45 & $20.0 \%$ \\
\hline & Business owner & 38 & $17.0 \%$ \\
\hline & Independent/self-employed & 30 & $13.0 \%$ \\
\hline & College student & 20 & $9.0 \%$ \\
\hline & Housewife & 18 & $8.0 \%$ \\
\hline
\end{tabular}


Table 1, cont.

\begin{tabular}{llll} 
& Unemployment & 14 & $6.0 \%$ \\
Retired & 7 & $3.0 \%$ \\
Monthly Income & Euro 1,000 or lower & 18 & $8.0 \%$ \\
& Euro 1,001-2,500 & 47 & $21.0 \%$ \\
& Euro 2,501 - 3,500 & 93 & $41.0 \%$ \\
& Euro 3,501 - or higher & 67 & $30.0 \%$ \\
Number of visit to Phuket & First time & 168 & $75.0 \%$ \\
& $2-3$ times & 40 & $18.0 \%$ \\
& 4 times and more & 17 & $7.0 \%$ \\
\hline
\end{tabular}

According to table 1, most of the respondents (53\%) were males and $47 \%$ were females. Most of them were in the age group of 31 - 45 years (33\%) and $46-59$ years old (31\%). More than half were married (62\%), and the majority (58\%) had education at the college level. The respondents came from different occupations, for example, $24 \%$ were company employees, $20 \%$ were government officers, $17 \%$ were business owner, and $13 \%$ were independent/self-employed. Nearly half of them (41\%) had monthly income in the range of Euro 2,501 - 3,500 while 30\% had income in the range of Euro 3,501 and higher, and 21\% earned approximately Euro 1,001 2,500 or lower. Most of them (75\%) were first time visitor, while 18\% visited Phuket 2-3 times, and 7\% return to Phuket 4 times and more. Among 225 European respondents, they came from UK (41), Germany (35), France (30), Sweden (27), Russia (25), Italy (15), Norway (13), Switzerland (11), Belgium (9), Spain (8), Austria (6) and eastern European countries (5).

Table 2: Mean score raking of tourist satisfaction towards Phuket
\begin{tabular}{|l|c|c|}
\hline \multicolumn{1}{|c|}{ Attribute satisfaction } & Mean & S.D. \\
\hline 1. Beaches/seasides & 4.45 & 0.78 \\
\hline 2. Natural environment/scenery & 4.39 & 0.91 \\
\hline 3. Friendliness of local people & 4.37 & 0.66 \\
\hline 4. Business services & 4.29 & 0.88 \\
\hline 5. Product and service quality & 4.27 & 0.79 \\
\hline 6. Tour/excursion & 4.25 & 1.15 \\
\hline 7. Cost of living & 4.19 & 0.97 \\
\hline 8. Local culture/attractions & 4.15 & 0.69 \\
\hline 9. Thai way of life & 4.14 & 0.74 \\
\hline 10. Leisure activities & 4.09 & 0.98 \\
\hline 11. A variety of shopping places & 4.02 & 0.99 \\
\hline 12. Reasonable prices of products/services & 3.99 & 0.85 \\
\hline 13. Local food & 3.95 & 0.86 \\
\hline 14. Nightlife/entertainment & 3.90 & 0.79 \\
\hline 15. Climate & 3.71 & 1.12 \\
\hline 16. Cleanliness & 3.70 & 1.08 \\
\hline 17. Safety & 3.32 & 0.88 \\
\hline 18. Local transportation & 3.30 & 0.64 \\
\hline 19. Overall satisfaction & 4.03 & 0.89 \\
\hline
\end{tabular}

Table 2 shows the mean score ranking of tourist satisfaction towards Phuket. The top three most satisfied attributes of Phuket are 1) beaches/seasides (mean=4.45), 2) natural environment/scenery (mean=4.39), and 3 ) friendliness of local people (mean=4.37). While the least three satisfied attributes are 1) cleanliness (mean=3.70), 2) safety (mean=3.32), and 3) local transportation (mean=330). However, the overall satisfaction was scored at 4.03. 
Table 3: Factor analysis of tourist satisfaction

\begin{tabular}{|c|c|c|c|c|}
\hline Factor dimensions (Cronbach's alpha) & Factor loading & Eigenvalue & Variance explained & Factor Mean \\
\hline Factor 1: Natural attraction (alpha $=0.81)$ & & 5.21 & 28.49 & 4.18 \\
\hline Beach/seaside & 0.88 & & & \\
\hline Natural environment/scenery & 0.73 & & & \\
\hline Climate & 0.65 & & & \\
\hline Factor 2: Local hospitality \& culture (alpha $=0.88)$ & & 2.24 & 11.32 & 4.10 \\
\hline Friendliness of local people & 0.85 & & & \\
\hline Cultural attractions & 0.73 & & & \\
\hline Local food & 0.71 & & & \\
\hline Thai way of life & 0.70 & & & \\
\hline \multicolumn{2}{|l|}{ Factor 3: Leisure \& recreation activities (alpha $=0.85)$} & 1.53 & 7.55 & 4.01 \\
\hline A variety of shopping places & 0.83 & & & \\
\hline Night life and entertainment & 0.81 & & & \\
\hline Leisure activities & 0.72 & & & \\
\hline Tours/excursion & 0.69 & & & \\
\hline Factor 4: Services and facilities (alpha $=0.74$ ) & & 1.75 & 8.98 & 3.98 \\
\hline Business services & 0.87 & & & \\
\hline Product and service quality & 0.81 & & & \\
\hline Reasonable prices of products and services 0.72 & & & & \\
\hline Cost of living & 0.70 & & & \\
\hline Local transportation & 0.69 & & & \\
\hline Factor 5: Safety \& cleanliness $($ alph $a=0.71)$ & & 1.35 & 6.86 & 3.5 \\
\hline Safety & 0.72 & & & \\
\hline Cleanliness & 0.69 & & & \\
\hline Total variance explained & $63.20 \%$ & & & \\
\hline
\end{tabular}

According to table 3, a factor analysis with varimax rotation was used to group satisfaction attributes. Five satisfaction factors were derived from the factor analysis of 18 satisfaction attributes. They were labeled as 1) natural attractions 2) local hospitality \& culture 3) leisure \& recreation activities 4) services \& facilities, and 5) safety \& cleanliness. Among them, natural attraction was the most satisfactory factor (mean=4.28). In this study, all satisfaction factors had eigenvalues greater than 1.0, and the items in each dimension had a factor loading greater than 0.4. In addition, Cronbach's alpha was calculated to test the internal consistency of items within each factor. The test showed that the alpha coefficients for the five factors ranged from 0.75 to 0.89 , well above the minimum value of 0.6 as an indication of reliability [3]. Thus, all five satisfaction factors were retained for the final structure for regression analysis.

Table 4: Regression analysis of satisfaction factors on destination loyalty

\begin{tabular}{|c|c|c|c|c|}
\hline Tourist satisfaction factors & Beta & t-value & Sig. & $\begin{array}{c}\text { Multicollinearity } \\
\text { (VIF value) }\end{array}$ \\
\hline 1. Natural attraction & 0.39 & 1.89 & $0.02 *$ & 1.06 \\
\hline 2. Local hospitality and culture & 0.28 & 1.67 & $0.01 *$ & 1.12 \\
\hline 3. Leisure/recreation activities & 0.11 & 2.25 & 0.45 & 1.25 \\
\hline 4. Services and facilities & 0.08 & 0.89 & 0.68 & 1.31 \\
\hline 5. Safety and cleanliness & 0.25 & 0.96 & $0.04 *$ & 1.47 \\
\hline
\end{tabular}

$\mathrm{R}^{2}=0.374$

Adjusted $\mathrm{R}^{2}=0.365$

Table 4 shows the finding of regression analysis and its coefficients (beta) indicating the relationships between independent variables (satisfaction factors) and dependent variable (destination loyalty). The finding indicates that 1) natural attraction, 2) Thai hospitality \& local culture, and 3) safety \& cleanliness had the impacts on destination loyalty $(p<0.05)$, and their relationships were positive. This may suggest that the respondents who are satisfied with natural attraction of Phuket, admiring Thai hospitality \& local culture, as well as feeling confident in 
safety in Phuket are more likely to revisit Phuket. Among the five satisfaction factors, the coefficients of natural attraction is greater than those of the four factors, suggesting that natural attraction is a more powerful variable to explaining destination loyalty in this study. However, other satisfaction factors, namely, leisure/recreation activities and services \& facilities are not found to be associated with the dependent variable. This suggests that these factors are not significant explanatory variables in destination loyalty.

\section{Recommendation}

Since the results of the current study reveal that tourists who are satisfied with natural attraction and local hospitality (macro level) are likely to revisit Phuket and recommend Phuket to others, the government and local authorities are therefore the key players in managing and planning these attributes in order to promote higher level of tourist satisfaction and create postpurchase behavior [1]. They may work together to manage these attributes through appropriate strategy, plan or project. In particular, the sustainable management approach should be emphasized. There should be also a regular monitor from city administrators/tourism officials to visit the beaches and natural areas in Phuket throughout the year to control the development, and quality of the tourism sites. Local authorities should pay more attention to the cleanliness of tourism sites by preparing sufficient staff and garbage bins throughout the city. Also, the city administrators/tourism officials may launch the campaign such as "Keep Phuket Clean". This campaign has been undertaken in several tourism destinations such as Bali, Indonesia and Penang, Malaysia. In addition, the government and local authorities should build the awareness and campaign for local people (including residents, venders, service staff) for being the good hosts in welcoming and assisting foreign visitors in Phuket. Regular campaigns or related activities may be established to build a good relationship between them such as beach cleaning, friendship sports, food festival, local events or other social events. Also, the safety in Phuket, local authorities and tourism polices should closely work together by providing more channels/information for emergency contact and having officials regularly visit the tourism sites throughout the city.

\section{Reference}

[1] C. Chi and H. Qu. Examining the structural relationships of destination image, tourists, satisfaction and destination loyalty: An integrated approach. Tourism Management Vol. 29 (2008), pp. 624-636.

[2] Department of Tourism. Internal Tourism 2014. Retrieved March 20, 2015 from http://www.tourism.go.th (2014)

[3] J. Hair, R. Anderson, R. Tatham R, and W. Black. Multivariate Data Analysis (6 ${ }^{\text {th }}$ ed.). New York: Prentice-Hall International (2006)

[4] C. Hsu. Mature motor-coach travelers' satisfaction: A preliminary step toward measurement development. Journal of Hospitality and Tourism Research. Vol. 20 (2003), pp. 1-19.

[5] A.K. Kim and G. Brown. Understanding the relationships between perceived travel experiences, overall satisfaction, and destination loyalty. Anatolia - An International Journal of Tourism and Hospitality Research. Vol. 23 (2012), pp. 328-347

[6] M. Kozak and M. Rimmington. Tourist satisfaction with Mallorca, Spain, as an OffSeason Holiday Destination. Journal of Travel Research. Vol. 38 (2000), pp. 260-269. 
[7] Y. Yoon and M. Uysal. An Examination of the effects of motivational and satisfaction on destination loyalty: A Structural Model. Tourism Management. Vol. 26 (2005), pp. 45-56. 